\title{
UJI EFEKTIFITAS EKSTRAK DAUN SRIKAYA (Anonna squamosa) TERHADAP KEMATIAN KECOA AMERIKA (Periplaneta americana)
}

\author{
Denai Wahyuni'), Reni Anggraini ${ }^{2)}$ \\ 1) Prodi Kesehatan Masyarakat STIKes Hang Tuah Pekanbaru \\ 2) Prodi Teknologi Laboratorium Medis Akademi Analis Kesehatan Yayasan Fajar Pekanbaru. \\ denaiwahyui69@gmail.com// 081371505039
}

\begin{abstract}
Cockroaches as mechanical vectors for some pathogenic microorganisms such as: Streptococus, Salmonella and contributing to spread diseases of dysentery, diarrhea, cholera, hepatitis A viruses and Polio. Controling of cockroaches presents using synthetic insecticides but it can be subtitutes by natural insecticides that called srikaya leaf extract. The aims of this study to looked the content of secondary metabolite compounds in srikaya leaves, determining the mortality of cockroaches and $L C_{50}$. This study used 6 cockroaches with concentrations of 5\%,10\%, 20\% and 30\%, $K(+)$ baygon, $K(-)$ aquades with 3 times replications and observed for 3 hours. The data were analyzed using Probit Analysis to determine $L C_{50}$. The result of identification of phytochemical compound, srikaya leaf contains flavonoid, saponin, alkaloid and tannin. The percentage mortality of cockroach at concentration 5\%, 10\%, 20\%, and 30\% respectively were $11,11 \%, 22,22 \%, 27,77 \%$, and $53,33 \%$ with $L_{50} 346.736 \mathrm{ppm}$.
\end{abstract}

Keywords: Effectiveness test, srikaya leaves, cockroach mortality

\section{PENDAHULUAN}

Vektor adalah organisme hidup yang dapat menularkan agen penyakit dari satu hewan ke hewan lain atau ke manusia. Arthropoda merupakan vektor penting didalam penularan penyakit parasit dan virus yang spesifik. Agen penyakit ini kemudian ditularkan kepada reservoir lain atau pada manusia (Chandra, 2006). Kecoa merupakan salah satu vektor, termasuk dalam phylum Arthropoda, kelas Insecta yang mempunyai bentuk tubuh oval dan pipih. Kecoa berperan sebagai vektor penyakit dan dekat kehidupannya dengan manusia (Sucipto, 2011).

Kecoa merupakan serangga yang hidup di dalam rumah, restoran, hotel, dapur dan lain-lain. Kecoa ini sangat dekat kehidupannya dengan manusia, menyukai bangunan yang hangat, lembab dan banyak terdapat makanan, hidupnya berkelompok dan aktif pada malam hari seperti di dapur, di tempat penyimpanan makanan, sampah, dan saluran-saluran air kotor. Pada siang hari bersembunyi di tempat gelap dan sering bersembunyi dicelah-celah. Kecoa ini dikatakan pengganggu karena mereka biasa hidup ditempat kotor dan dalam keadaan terganggu mengeluarkan cairan yang berbau tidak sedap (Zaman, 2010).

Kecoa Amerika (Periplaneta americana) salah satu jenis yang berbahaya, karena memiliki perilaku memakan makanan dan kotoran lalu memuntahkan kembali sebagian makanan yang telah dicernanya dan menyukai tempat seperti saluran pembuangan air limbah, septik tank, selokan dan tempat sampah. Peranan kecoa dalam penularan penyakit antara lain sebagai inang perantara bagi beberapa spesies cacing dan sebagai 
vektor mekanik bagi beberapa mikro organisme patogen seperti: Streptococus, Salmonella dan lain-lain sehingga berperan dalam penyebaran penyakit disentri, diare, kolera, virus hepatitis A dan Polio. Sekresi air liur dan debu tinja kecoa dapat menyebabkan reaksi alergi pada kulit seperti dermatitis, gatal-gatal dan pembengkakan kelopak mata (Sucipto, 2011).

Pengendalian kecoa yang biasa dilakukan adalah dengan 3 metode yaitu; pengendalian secara fisik dan mekanik, pengendalian secara biologi serta pengendalian secara kimia. Pemakaian insektisida sintetik dapat menimbulkan dampak negatif terhadap manusia, lingkungan dan organisme lain. Bagi manusia sebagai pengguna dapat menimbulkan keracunan akut, bagi lingkungan dapat mencemari air, udara dan tanah. Sementara bagi organisme lain dapat membunuh musuh alami dari hama dan resistensi hama pada pestisida. Sebagaimana yang diungkapkan oleh Sucipto (2011) pengunaan insektisida sintetik memiliki kekurangan yang terbuat dari bahan-bahan kimia yang umumnya dapat meninggalkan residu bagi manusia dan berdampak negatif terhadap lingkungan, pada manusia bisa mengakibatkan keracunan jika tertelan dan dalam waktu jangka panjang akan menyebabkan terjadinya resistensi.

Oleh sebab itu maka perlu dilakukan alternatif lain untuk mengendalikan kecoa dari tanaman yang memiliki senyawa yang dapat membunuh serangga tetapi tidak mempunyai efek samping terhadap lingkungan dan tidak berbahaya bagi manusia. Salah satu cara yang dapat dilakukan yaitu dengan menggunakan insektisida nabati yang berasal dari ekstrak tumbuhan. Salah satu tanaman yang berpotensi sebagai insektisida nabati adalah daun srikaya (Anonna squamosa)

Daun srikaya

(A. squamosa) merupakan tanaman yang dikenal oleh masyarakat Indonesia sebagai tanaman obat tradisional untuk mengobati berbagai penyakit. Bagian daun dari tumbuhan ini dapat mengatasi batuk, rematik, gangguan saluran pencernaan dan dapat juga sebagai menambah stamina, serta pereda demam (Agromedia, 2008). Daun srikaya juga mengandung senyawa saponin, tanin, dan triterpenoid (Tansil., dkk 2015)

Penelitian oleh Purwaningsih., dkk (2015) menyatakan daun srikaya kaya akan senyawa flavonoid yang terbukti dapat menghancurkan dinding kulit larva Aedes aegypyi dan saluran pencernaan larva, sehingga larva nyamuk $A$. aegypti dapat mati. Penelitian yang telah dilakukan oleh Astuti., dkk (2014) dengan bahan tumbuhan lain yaitu menggunakan ekstrak daun sirsak dengan konsentrasi 3\%, 4\%, dan 5\%. Menunjukkan bahwa semakin tinggi konsentrasi yang dilakukan semakin banyak kecoa yang mati dan kematian yang tertinggi pada konsentrasi 5\%. Hal ini disebabkan karena ekstrak daun sirsak mengandung senyawa flavonoid, saponin, dan tanin yang dapat mematikan kecoa amerika. Selanjutnya, penelitian yang dilakukan oleh Krisman., dkk (2016) menggunakan ekstrak daun belimbing wuluh dengan 3 pelarut yaitu etanol, etil asetat dan nheksan dimana masing-masing pelarut menggunakan konsentrasi 12,\%, 25,\%, 37,\%, dan $50, \%$ menunjukan semua pelarut dapat mematikan kecoa amerika dengan kematian tertinggi $50 \%$ pada ekstrak n-heksan. Kematian kecoa terjadi karena ekstrak daun belimbing wuluh mengandung senyawa terpenoid dan steroid.

Penelitian ini bertujuan melihat kandungan senyawa metabolit sekunder yang terdapat dalam daun srikaya, menentukan mortalitas kecoa amerika dan nilai $\mathrm{LC}_{50}$

2 METODOLOGI PENELITIAN

Lokasi dan Waktu Penelitian 
Penelitian ini dilakukan di Laboratorium Mikrobiologi \& Parasitologi AAK Yayasan Fajar Univ. Abdurrab Pekanbaru dan Laboratorium Kimia Organik Fakultas Matematika dan Ilmu Pengetahuan Alam (FMIPA) Universitas Riau Pekanbaru pada bulan November-Desember 2017

\section{Serangga Uji}

Populasi dalam penelitian ini adalah seluruh kecoa yang dikumpulkan dengan cara penangkapan secara manual dengan menggunakan perangkap sederhana dan membeli dari pasar hewan. Kecoa yang digunakan sebagai sampel/ hewan uji adalah kecoa yang telah dewasa dan bergerak aktif. Sampel pengujian untuk masing-masing konsentrasi terdiri dari 6 ekor kecoa, dengan total sampel keseluruhan berjumlah 108 ekor.

\section{Tanaman Sumber Ekstrak}

Daun srikaya yang digunakan dalam penelitian ini didapatkan dari pohon srikaya di perumahan yang berada di daerah Riau Ujung Kota Pekanbaru.

\section{Pembuatan Ekstrak Daun Srikaya}

Diambil daun srikaya yang masih segar sebanyak 2000 gr, dicuci hingga bersih lalu dikeringkan dengan cara dianginkan di dalam suhu ruangan dan terhindar dari sinar matahari langsung. Setelah kering dilanjutkan pengeringan dengan menggunaan oven di laboratorium pada suhu $40^{\circ} \mathrm{C}$. Daun srikaya yang sudah dikeringkan lalu diblender sampai halus dan selanjutnya direndam dengan larutan etanol 96\% sampai benar-benar terendam sempurna (maserasi) pada tabung atau toples selama 3 hari sambil sesekali diaduk, lalu filtrat yang diperoleh sebelumnya dimasukan ke dalam alat Rotary vacum evaporator untuk memisahkan ekstrak daun srikaya dan pelarutnya, hingga didapatkan ekstrak kental. Ekstrak yang sudah didapatkan disimpan dalam lemari pendingin sampai saat akan digunakan.

\section{Metoda Pengujian}

Penelitian ini menggunakan 4 konsentrasi ekstrak daun srikaya yaitu 5\%, $10 \%, 20 \%$ dan $30 \%$ dan $\mathrm{K}(+)$ menggunakan baygon, $\mathrm{K}(-)$ menggunakan akuades dengan 3 kali ulangan. Untuk mendapatkan konsentrasi $5 \%$ : 0,25 gram ekstrak daun srikaya ditambahkan akuades sebanyak 4,75 $\mathrm{ml}$ dan dimasukkan ke dalam botol srayer dan demikian untuk konsentrasi selanjutnya.

\section{Pelaksanaan pengujian}

Hasil ekstrak daun srikaya dimasukkan ke dalam botol spayer dengan empat macam konsentrasi yaitu 5\%, 10\%. 20\%, dan 30\%, untuk kontrol negatif menggunakan akuades, kontrol positif menggunakan baygon. Disiapkan kotak percobaan lalu masukkan 6 ekor kecoa amerika dewasa pada tiap kotak, lalu disemprotkan masing-masing konsentrasi tersebut. Selanjutnya dilakukan pengamatan setelah 3 jam penyemprotan lalu dihitung jumlah kecoa yang mati pada masing-masing kotak percobaan. Pada akhir setiap perlakuan, kecoa yang tidak mati pada akhir pengamatan didiamkan sampai mati sendiri atau dibunuh dengan menggunakan baygon. Hal ini dilakukan pada masing-masing pengulangan kedua dan ketiga. Pengamatan perilaku kecoa dengan melihat kondisi perubahan tingkah laku, gerak dan kondisi fisik yang terjadi setelah pemberian ekstrak daun srikaya.

\section{Identifikasi Senyawa Fitokimia}

Hasil ekstraksi daun srikaya dari pelarut etanol dilakukan uji secara kualitatif untuk mengetahui kandungan senyawa metabolit sekunder yang ada di dalam ekstrak daun srikaya tersebut. Identifikasi senyawa 
fitokimia yang dilakukan adalah uji saponin, flavonoid, fenolik tanin dan alkaloid.

\section{Analisa Data}

Data yang diperoleh dari hasil percobaan disajikan dalam bentuk tabel, dilanjutkan dengan Analisis Probit untuk melihat efektifitas insektisida ekstrak daun srikaya terhadap mortalitas kecoa amerika berdasarkan $\mathrm{LC}_{50}$.

\section{HASIL DAN PEMBAHASAN}

\section{A. Hasil Penelitian}

Efek paparan ekstrak daun srikaya terhadap kecoa pada berbagai konsentrasi perlakuan, kecoa tampak gelisah melakukan gerakan turun naik, tubuh melemah dan tidak dapat menggerakan badan sehingga mati. Warna tubuh kecoa berubah menjadi kehitaman akibat ekstrak yang telah disemprotkan

\section{Identifikasi Senyawa Fitokimia}

Hasil Ekstraksi daun srikaya dari pelarut etanol dilakukan uji secara kualitatif untuk mengetahui kandungan senyawa metabolit sekunder yang ada di dalam ekstrak daun srikaya tersebut. Hasil identifikasi kandungan senyawa fitokimia dari ekstrak daun srikaya dapat dilihat pada Tabel 1.

\section{Tabel 1 Hasil Identifikasi Senyawa Fitokimia Ekstrak Daun Srikaya}

\begin{tabular}{lllll}
\hline No & Golongan senyawa & Pereaksi & Hasil & Ket \\
\hline a. & Saponin & Akuades & $\begin{array}{l}\text { Busa bertahan selama } 5 \\
\text { menit }\end{array}$ & $(+)$ \\
b. & Flavonoid & Logam Mg dan HCL & Jingga & $(+)$ \\
c. & Fenolik & $\mathrm{FeCl}_{3} 5$ & Hitam kecoklatan & $(-)$ \\
d. & Tanin & $\mathrm{FeCl}_{3}$ & Hitam kehijauan & $(+)$ \\
e. & Alkaloid & Mayer & Terbentuknya endapan $(+)$ \\
& & & putih & \\
\hline
\end{tabular}

Keterangan (+) : memiliki kandungan senyawa

Keterangan (-) : tidak memiliki kandungan senyawa

Hasil dari identifikasi kandungan senyawa fitokimia ekstrak daun srikaya didapatkan adanya senyawa saponin, flavonoid, tanin, dan alkaloid.

\section{Uji Mortalitas Kecoa Amerika} Menggunakan Ekstrak Daun Srikaya

Pengujian mortalitas kecoa amerika ini menggunakan ekstrak daun srikaya yang telah terbukti memiliki kandungan senyawa metabolit yang diinginkan melalui identifikasi senyawa fitokimia. Hasil mortalitas kecoa amerika setelah diberikan ekstrak daun srikaya selama 3 jam dapat dilihat pada Tabel 2 di bawah ini

\section{Tabel 2 Hasil Mortalitas Kecoa Amerika Setelah Pemberian Ekstrak Etanol Daun Srikaya Selama 3 Jam}

\begin{tabular}{|c|c|c|c|c|c|c|}
\hline \multirow{3}{*}{ No } & \multirow{3}{*}{ Konsentrasi Ekstrak } & \multicolumn{4}{|c|}{ Jumlah Kecoa amerika dewasa yang mati } & \multirow{3}{*}{$\begin{array}{c}\text { Persentase } \\
\text { Kematian } \\
\text { Kecoa }(\%)\end{array}$} \\
\hline & & \multicolumn{3}{|c|}{ Pengulangan } & \multirow{2}{*}{ Rata-rata } & \\
\hline & & 1 & 2 & 3 & & \\
\hline 1 & $5 \%$ & 1 & 0 & 1 & 0,66 & 11,11 \\
\hline 2 & $10 \%$ & 2 & 1 & 1 & 1,33 & 22,22 \\
\hline 3 & $20 \%$ & 2 & 2 & 1 & 1,66 & 27,77 \\
\hline 4 & $30 \%$ & 4 & 3 & 3 & 3,33 & 53,33 \\
\hline
\end{tabular}




\begin{tabular}{lllllll}
\hline 6 & Kontrol (+) & 6 & 6 & 6 & 6 & 100,00 \\
\hline 7 & Kontrol (-) & 0 & 0 & 0 & 0 & 0 \\
\hline
\end{tabular}

Berdasarkan Tabel 2 di atas dapat mencapai $100 \%$ dan pada kontrol negatif dilihat bahwa setelah pemberian ekstrak daun menggunakan akuades menunjukkan tidak srikaya yang diamati selama 3 jam terjadi kematian pada kecoa. Konsentrasi menunjukkan masing-masing konsentrasi dari ekstrak daun srikaya yang telah digunakan ekstrak daun srikaya dapat membunuh kecoa menunjukkan adanya kandungan toksik yang amerika. Hasil uji yang telah dilakukan, dapat membunuh kecoa amerika dewasa. terhadap kecoa amerika dengan menggunakan Besarnya kandungan toksik tersebut dapat ekstrak etanol daun srikaya pada konsentrasi diketahui dengan mencari nilai LC C $_{0}$ (Lethal $5 \%, 10 \%$, 20\%, dan $30 \%$ adalah $11,11 \%$, concentration 50) melalui rumus linear yang $22,22 \%, 27,77 \%$, dan $53,33 \%$. Kematian diperoleh dari grafik nilai probit mortalitas kecoa amerika terendah pada konsentrasi 5\% kecoa amerika terhadap daun srikaya. Data yang mencapai $11,11 \%$ dan kematian tertinggi grafik nilai probit dapat dilihat pada Tabel 3 pada konsentrasi $30 \%$ yaitu 53,33\%. Pada dan grafik nilai probit mortalitas kecoa kontrol positif menggunakan baygon amerika terhadap ekstrak daun srikaya, dapat menunjukan adanya kematian kecoa yang dilihat pada Gambar 1.

Tabel 3 Data Grafik Nilai Probit Mortalitas Ekstrak Daun Srikaya Terhadap Kecoa Amerika.

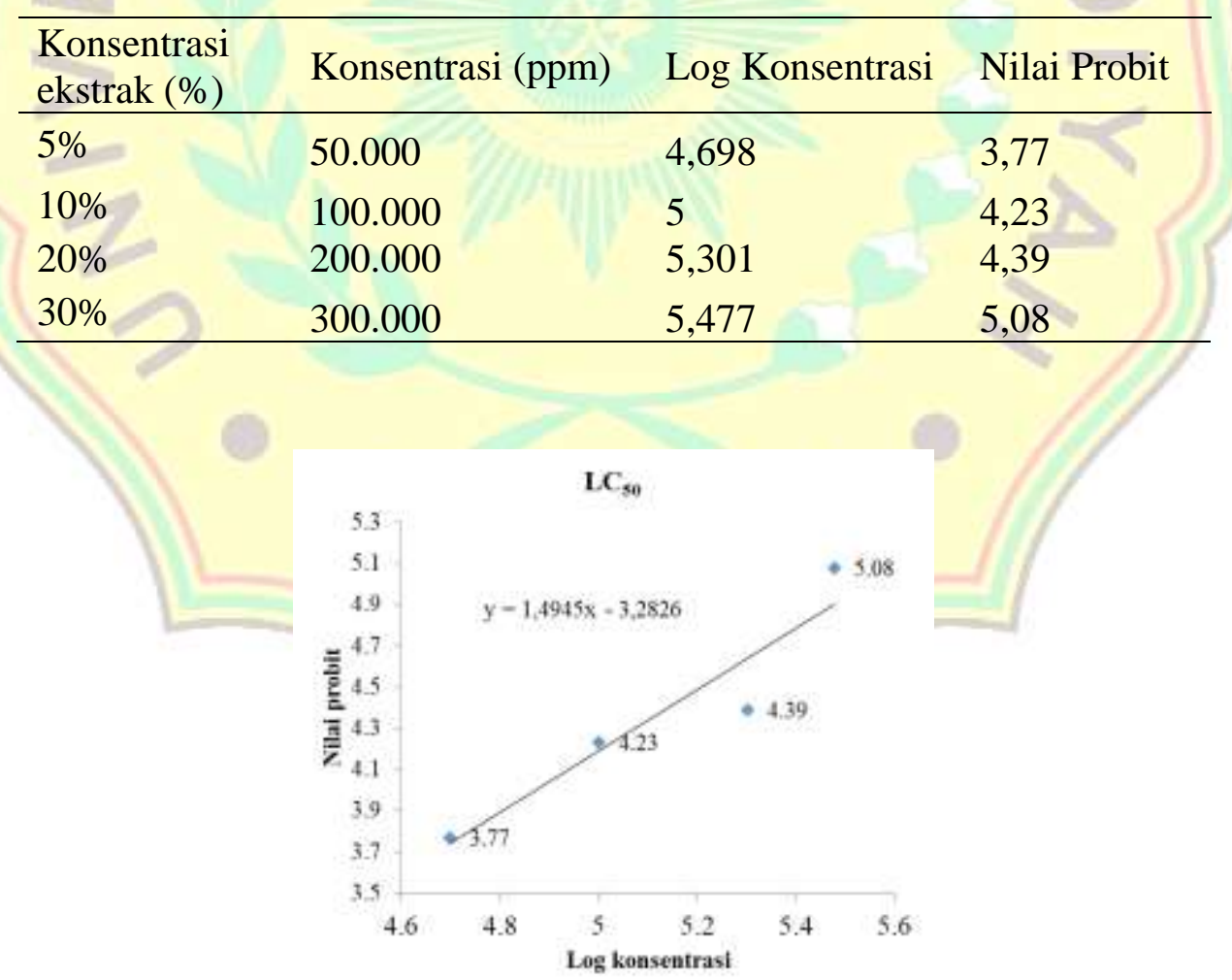

Gambar 1 Grafik Nilai Probit Mortalitas Kecoa Amerika Terhadap Ekstrak Daun
Srikaya. 
Berdasarkan grafik nilai probit mortalitas ekstrak daun srikaya terhadap kecoa amerika, dapat dilihat dengan jelas terjadi peningkatan kematian kecoa amerika dari konsentrasi ekstrak yang terkecil hingga konsentrasi ekstrak yang terbesar. Selain itu didapatkan nilai $\mathrm{LC}_{50}$ dari grafik mortalitas kecoa amerika tersebut sebesar 346.736,85 ppm. LC50 adalah suatu perhitungan untuk menentukan keaktifan dari suatu ekstrak dan menunjukan konsentrasi ekstrak yang dapat mematikan kecoa yang di uji sebanyak 50\% pada waktu tertentu (Wahyuni dkk 2016).

\section{B. Pembahasan}

Hasil uji fitokimia pada ekstrak daun srikaya, positif mengandung senyawa aktif tanin, saponin, flavonoid dan alkaloid. Berdasarkan penelitian yang dilakukan oleh Astuti dan Soekardi (2014), penyebab kematian pada serangga disebabkan oleh kandungan metabolit dari daun srikaya yaitu saponin, flavonoid, tanin, dan alkaloid.

Berdasarkan Tabel 4.2 menunjukkan bahwa pada setiap konsentrasi yang berbeda didapatkan jumlah kecoa amerika yang mati berbeda. Hal ini menunjukkan bahwa semakin tinggi konsentrasi, maka semakin tinggi angka kematian dari kecoa amerika. Jumlah kematian kecoa amerika tergantung pada jumlah senyawa yang terkandung pada tiap-tiap konsentrasi, dimana semakin tinggi konsentrasi maka kandungan senyawa insektisida yang bersifat sebagai racun bagi serangga akan lebih banyak (Kardinan, 2009).

Pada penelitian ini kematian kecoa amerika ditandai dengan tidak bergeraknya saat disentuh dengan pingset. Efek paparan ekstrak daun srikaya terhadap kecoa pada berbagai konsentrasi perlakuan, kecoa tampak gelisah dan lebih aktif melakukan gerakan turun naik, setelah beberapa lama tubuh melemah dan tidak dapat menggerakan badan sehingga mati dan tubuh yang mati kelihatan kaku. Warna tubuh kecoa berubah menjadi hitam akibat ekstrak yang telah disemprotkan

Dari hasil pengamatan yang dilakukan pada kecoa dimana tubuh kecoa diam dan mati hal ini di sebabkan oleh adanya senyawa flavonoid yang merupakan racun pernafasan. Senyawa flavonoid yang dihirup oleh kecoa mempengaruhi pada pernapasan kecoa sehingga tubuh melemah dan menyebabkan kelemahan pada syaraf. Yunikawati dkk, (2013) menjelaskan bahwa flavonoid merupakan inhibitor pernapasan dengan mekanisme yang dapat melemahkan saraf. Flavonoid salah satu golongan fenol alam terbesar yang mempunyai kecenderungan untuk mengikat protein sehingga mengganggu proses metabolisme. Selain itu, Cania dan Endah, (2013) menjelaskan bahwa senyawa flavonoid akan masuk ke dalam tubuh serangga melalui sistem pernapasan yang berupa spirakel, sehingga menimbulkan kelemahan pada sistem saraf dan kerusakan pada sistem pernapasan yang menyebabkan kematian pada serangga akibat tidak bisa bernapas.

Selain dari flavonoid, pada ekstrak daun srikaya juga terdapat tanin. Menurut Purwita dkk, (2013) tanin merupakan salah satu jenis senyawa yang termasuk kedalam golongan polifenol. Senyawa tanin dapat menginduksi pembentukan kompleks ikatan tanin terhadap ion logam yang dapat menambah daya toksisitasnya sehingga dapat merusak membran sel serangga. Mekanisme kerja tanin diduga dapat mengkerutkan dinding sel atau membran sel sehingga mengganggu permeabilitas sel yang mengakibatkan sel tidak dapat melakukan aktivitas hidup sehingga pertumbuhannya terhambat dan mengalami kematian.

Saponin yang termakan oleh kecoa mengakibatkan tubuh kecoa lemah dan mati, karena senyawa saponin dapat mengakibatkan 
penurunan asupan nutrisi. Menurut Heras dan Hortelano (2009), senyawa saponin dapat menghambat bahkan membunuh serangga, saponin dapat merusak membran sel dan mengganggu proses metabolisme serangga. Mekanisme saponin masuk ke dalam tubuh serangga adalah dengan cara inhibisi terhadap enzim protease yang mengakibatkan penurunan asupan nutrisi oleh serangga dan membentuk kompleks dengan protein dan menyebabkan serangga mati.

Alkaloid memiliki kemampuan dengan cara mengganggu komponen penyusun peptidoglikan pada sel, sehingga pada lapisan dinding sel tidak terbentuk secara utuh dan menyebabkan kematian sel tersebut dan alkaloid sering kali beracun (Arlofa 2015). Cania dan Endah (2013) menjelaskan alkaloid dapat berperan sebagai racun saraf dengan cara menghambat kerja dari enzim saraf, sehingga akan terjadi kegagalan fungsi dari sistem saraf yang akhirnya akan menyebabkan kekakuan pada sistem penghantar impuls menuju sistem otot. Kondisi ini mengakibatkan otot kejang, knockdown dan menyebabkan kematian pada serangga. Hal ini terlihat dari kematian kecoak dimana tubuh kecoak kejang lalu mati dan tubuh yang mati kelihatan kaku

Pada kontrol negatif (-) menggunakan akuades tidak ditemukan kecoa amerika yang mati, karena akuades tidak bersifat sebagai toksit. Pada Kontrol positif (+) menggunakan baygon dengan kandungan sipermetrin, ditemukan kecoa amerika yang mati, yang ditandai dengan lumpuhnya pergerakan dari serangga, karena sipermetrin ini adalah salah satu golongan insektisida yang memang peruntukannya digunakan sebagai membunuh serangga (Raini, 2009).

\section{KESIMPULAN DAN SARAN}

Hasil identifikasi senyawa Fitokimia, daun srikaya mengandung senyawa flavonoid, saponin, alkaloid dan tanin. Persentase mortalitas kecoa amerika pada konsentrasi 5\%, $10 \%$, 20\%, dan $30 \%$ berturut-turut yaitu $11,11 \%, 22,22 \%, 27,77 \%$, dan $53,33 \%$ dengan nilai $\mathrm{LC}_{50} 346.736$ ppm.

\section{UCAPAN TERIMA KASIH}

Penulis mengucapkan terima kasih kepada Laboratorium Mikrobiologi \& Parasitologi Yayasan AAK Fajar Universitas Abdurrab Pekanbaru dan Laboratorium Kimia Organik Fakultas Matematika dan Ilmu Pengetahuan Alam Universitas Riau Pekanbaru yang telah bersedia sebagai tempat pelaksanaan penelitian dan kepada semua pihak yang telah membantu saran dan petunjuk sehingga penelitian telah berhasil dilaksanakan.

\section{DAFTAR PUSTAKA}

Arlofa, N. 2015. Uji Kandungan Senyawa Fitokimia Kulit Durian Sebagai Bahan Aktif Pembuatan Sabun. Jurnal Chemtech. Volume 1 (1): Halaman 18 22.

Astuti, R., dan Soekardi, H. 2014. Pengaruh Ekstrak Daun Sirsak (Annona muricata L) Terhadap Mortalitas Kecoa Amerika (Periplaneta americana) Dewasa. Jurnal Pengembangan Teknologi Pertanian. Volume 7 (2): Halaman 292 - 298.

Agromedia. A. 2008. Buku Pintar Tanaman Obat. Cetakan ke-1. PT Agromedia Pustaka. Jakarta

Cania, B., dan Endah. 2013. Uji Efektivitas Larvasida Ekstrak Daun Gelundi (Vitex Trifolia) Terhadap Larvasida Aedes aegypti. Jurnal Kesehatan Universitas Lampung. Volume 2 (4): Halaman 52 180.

Chandra, B. 2007. Pengantar Kesehatan Lingkungan. Jakarta: EGC.

Kardinan, A. 2009. Daya Tolak Ekstrak Tanaman Rosemary (Rosmarinus 
OfficinalisI) Terhadap Lalat Rumah (Musca domestica). Jurnal Bul Littro. Volume 18 (2): Halaman 170 - 176.

Krisman, Y., Ardiningsih, P., dan Syahbanu, I. 2016. Aktivitas Bioinsektisida Ekstrak Daun Belimbing Wuluh (Averrhoa bilimbi) Terhadap Kecoa (Periplaneta americana). Jurnal Jkk. Volume 5 (3): Halaman $1-7$.

Purwaningsih. N. V., Kardiwinata. M. P., dan Utami. N. W. A. 2015. Daya bunuh ekstrak daun srikaya (Annona squamosa) Terhadap Telur dan Larva A. aegypti. Jurnal Cakra Kimia. Volume 3(2): Halaman 96-102.

Purwita. A., Indah. K. N., Trimulyono. G. 2013. Penggunaan Ekstrak Daun Srikaya (Anonna squamosa) Sebagai Pengendali Jamur Fusarium Oxysporum Secara In Vitro. Jurnal Unesa. Volume 2(2): Halaman 179-183.

Raini, M. 2009. Toksikologi Insektisida Rumah Tangga dan Pencegahan Keracunan. Media Peneliti dan Media Pengembangan Kesehatan. Volume 19 (1) : Halaman $527-533$.
Sucipto, C.D. 2011. Vektor Penyakit Tropis. Yogyakarta: Gosyen Publishing.

Tansil. A. Y. M., Posangi. J., dan Bara. R. A. 2016. Uji Daya Hambat Ekstrak etanol daun srikaya (Annona squamosa) Terhadap Pertumbuhan Bakteri Escherichia coli dan Staphylococcus aureus. Jurnal e-biomedik. Volume 4(2): Halaman 1-5.

Wahyuni, D., Latif, A., dan Asyari, K. 2016. Formulasi $\mathrm{LC}_{50}$ Bioinsektisida Baru Ekstrak Biji Pepaya (Carica papaya L.), Biji Srikaya (Anona squamosa L.) Dan Biji Alpukat (Persea americana MILL.) Terhadap Mortalitas Larva Nyamuk Aedes aegypti L. Jurnal Sains dan Teknologi. Volume 1(3): Halaman 118123.

Yunikawati. M. P., Bejung. K. N., Mahatmi. H. 2013. Efektifitas Perasan Daun Srikaya Terhadap Daya Hambat Pertumbuhan Escherichia coli. Jurnal Indonesia Medicus Veterinus. Volume 2(2): Halaman 170-179.

Zaman, V. 2010. Buku Penuntun Parasitologi Kedokteran. Indonesia Bina Cipta. Bandung 